\title{
Law Strength of Notary Deed in Legality Strengthening Of the BUMDes in Perspective of Permendesa No.4 Of 2015 (Studies on Village-Owned Enterprises of Semarang)
}

\author{
Medina Praba Andini ${ }^{1}$, Hari Condro Wibisono ${ }^{2}$ and Achmad \\ Sulchan $^{3}$
}

Abstract. The purpose of this study were 1) Aim and analyze the legal force of Deed in strengthening the legality of the establishment of village-owned enterprises be seen in the perspective of PERMENDESA No. 4 of 2015 (Studies in the village-owned enterprises of Semarang), 2) Aim and analyze the weaknesses and solutions Deed in the preparation of the establishment of village-owned enterprises in Semarang.

The approach used in this study is a sociological juridical approach, sociological juridical approach is to identify and conceptualize law as a social institution that is real and functional in a real life system. Specifications research used in this study is descriptive analytical, analytical descriptive study sought to describe the legal issues, the legal system and to study it or analyze it according to the needs of the research in question.

Based on the results of data analysis concluded that: 1) BUMDes established by Regulation village formed by the village government and village Permusyawatan Board by consensus together. In addition to the legitimacy of the establishment of Village Regulations as BUMDes, reality on the ground there are some BUMDes in Semarang which have included Deed in strengthening the legality of the establishment. Deed as reinforcement of legality establishment BUMDes have binding legal force that can provide legal certainty and legal protection in the future, 2) weaknesses in the establishment Deed preparation BUMDes based research are: 1. Each BUMDes will have the format of AD / ART different and certainly not the same as the standard format of a Notary Public. 2. References are minimal regarding creation BUMDes Deed of Establishment. Because in PERMENDESA No. 4 of 2015 only confirmed that each village can form BUMDes under Regulation village. Recording BUMDes establishment in the Deed is an initiative of the board BUMDes itself. The solution of these weaknesses is the knowledge and experience related notary deed BUMDes. Associated with the solution that has been mentioned in addition to the importance of the knowledge and experience of a Notary in making a deed, but also Notaries need to provide clarification of the law, the deed was made since the implementation of the duty office of Notary "Esteroic" which means needed special education and sufficient capacity to run, as in the case of duties required accuracy, precision and accuracy. In addition, the Notary as public officials must be sensitive, responsive, has a sharpness of thinking and able to provide a proper analysis of any legal phenomenon and social phenomenon that appears so so will cultivate an attitude of courage in taking appropriate action.

Keywords: Owned Village; Deed; Severability.

1 Students Master of Notary Faculty of Law UNISSULA, Semarang E-mail: medinaandini174@gmail.com.

2 Students of Master of Law, Faculty Of Law, Universitas Islam Sultan Agung email condro33@yahoo.com

${ }^{3}$ Lecturer of Faculty of Law UNISSULLA, email: ach.sulchan@unissula.ac.id 


\section{Introduction}

Village-owned enterprises (BUMDes) is a form of village government efforts to utilize all the potential that there is good potential for natural resources or human. In the explanation of Act No. 6 of $2014^{4}$ about the village explained that BUM specific village can not be equated with legal entities, such as PT, CV, or Cooperation. BUMDes is a business entity characterized by the village. SetNPWPgs on the BUM The village is set in a more specific in the Ministerial Regulation No. 4 of 2015 Village on the Establishment, Management and Administration, and the dissolution of the villageowned enterprises. BUMDes is a business entity of all or most of its capital owned by the village through direct participation from the wealth of the village were separated in order to manage assets, services, and other businesses for the welfare of the villagers. ${ }^{5}$

Village-owned enterprises intended as an attempt to accommodate all the activities in the field of economic and / or public services managed by the village and / or cooperation among villages. The establishment of the BUMDes aims:

- Improve the economy of the village;

- Optimizing asset village to be useful for the welfare of the village;

- Improving the business community in the management of the economic potential of the village;

- Develop a plan of cooperation between rural businesses and / or with third parties;

- CreaNPWPg opportunities and market networks that support public service needs of citizens;

- Create jobs;

- Improve social welfare through the improvement of public services, economic growth and equitable distribution of the village; and

- Increase people's income and revenue village Desa. ${ }^{6}$

Establishment and management of village-owned enterprises (BUMDes) is a manifestation of the rural economic management is done with a spirit of brotherhood and togetherness. So BUMDes can run as it needs to be a serious effort and maximal management of various aspect. Seeing from a legal standpoint, legality establishment of BUMDes greatly affect how the Village to the future. Legality, legal status, and a clear legal framework can be the basis BUMDes run on village activity. If BUMDes wants to do legal relationship with third parties legality, legal status and legal protection is what will make a third-party trust and believe to cooperate with the BUMDes.

In the village of Regulation No 4 of $2015^{7}$ on the Establishment, Management and Administration, and the dissolution of the village-owned enterprises Article 5 (1) confirmed that the establishment of BUMDes agreed through Village Consultation, as stipulated in the Regulation of the Minister of Rural, Rural Development, and the Transmigration of the Code of Conduct and Mechanism Decision Deliberation Village. Furthermore, in paragraph (3) of this article explained that the agreement deliberation Village as a guide for the village government and Village Consultative Body to establish Village Regulations on the Establishment of Rural BUM.

\footnotetext{
${ }^{4}$ Act 6 of 2014 about the village.

${ }^{5}$ Regulation of the Minister of Rural 42015 On the Establishment, Management and Administration, and the dissolution of the village-owned enterprises Article 1 paragraph 2.

${ }^{6}$ Regulation of the Minister of Rural 42015 On the Establishment, Management and Administration, and the dissolution of the village-owned enterprises Article 3.

${ }^{7}$ Ibid, Article 5.
} 
$B U M$ can be explained that the village is one of the economic institutions are expected to contribute towards revenue sources of village. In the presence BUMDes need to get a legal entity's establishment can be a guarantee in the future. If the establishment of village-owned enterprises are in accordance with the criteria for the establishment of a legal person and perform legal relationship is a necessity, then how does the force of law related to the strengthening of Deed of the legality of the establishment of the BUMDes. Based on the above, the research problem is formulated as follows: Firstly how enforceable Deed in strengthening the legality of the establishment of villageowned enterprises be seen in the perspective of PERMENDESA No. 4 of 2015 (Studies in the village-owned enterprises of Semarang, Second how weaknesses and Deed preparation solution in the establishment of village-owned enterprises (Study on village-owned enterprises of Semarang) ".

This research seeks to assess and analyze the legal force of Deed in strengthening the legality of the establishment of village-owned enterprises be seen in the perspective of PERMENDESA No. 4 of 2015 (Studies in the village-owned enterprises of Semarang) as well as reviewing and analyzing the weaknesses and the solution preparation of the Deed in founding Enterprises Owned village in the Semarang.

\section{Research methods}

The method used in this study using sociological juridical approach. Sociological juridical approach is to identify and conceptualize law as a social institution that is real and functional in a real life system. ${ }^{8}$

The data source of this research include: 1 . Primary Data, Primary data is data obtained directly from the source, either through interviews, observations, and reports in the form of informal document which is then processed by the researcher. ${ }^{9}$

Sources of data in this study was obtained through the method of interviews with the parties concerned (speakers) that party is the Head of Community Empowerment and Rural Semarang,Head of the village in the Semarang (sample), Business BUMDes in Semarang (sample), Notary in Batang (sample). 2. Secondary Data, Secondary data is data obtained from official documents, books related to the object of research, the results of research in the form of reports, thesis, dissertation, and legislation. ${ }^{10}$

\section{Results and Discussion}

\subsection{Law Strength of Notary Deed in Legality Strengthening Of the Bumdes in Perspective of Permendesa No.4 of 2015 (Studies on Village-Owned Enterprises of Semarang)}

Village-owned enterprises (BUMDes) are entities that exist in the village that was formed by the village government along Village Community. The purpose of the establishment of village-owned enterprises as well as in the Minister of Rural, Rural Development and Transmigration No. 4 of $2015^{11}$ On the Establishment, Management, Management, and Dissolution of the village-owned enterprises Article 2 is "The establishment of village-owned enterprises is intended as an attempt to accommodate

\footnotetext{
${ }^{8}$ Soerjono Soekanto, 1986, Pengantar Penelitian Hukum, UI Press, Jakarta, p. 51.

${ }^{9}$ Zainuddin Ali, 2009, Metode Penelitian Hukum, Sinar Grafika, Jakarta, p. 106.

${ }^{10}$ Ibid

${ }^{11}$ Op.cit, Article 2.
} 
all the activities in the field of economic and / or public services managed by the village and / or cooperation between the Village".

The formation of village-owned enterprises not only profit-oriented, but also oriented to support the improvement of public welfare village. Therefore the village-owned enterprises in carrying out its activities should have a definite legal justification as the basis for the establishment as a business entity.

As a Business Entity provisions regarding BUMDes as business entities with legal status are not described explicitly in this Regulation. In the PERMENDESA No. 4 of 2015 Article 7 explained: BUMDes may consist of units of a legal entity. The unit of a legal entity can be a business shareholding Institutions derived from BUMDes and society. In case BUMDes not have business units with legal status, form BUMDes organization based on the Regulation on the Establishment BUMDes. ${ }^{12}$

In contrast to other business entities such as limited liability companies, CV, cooperative use as the basis for its establishment notarial deed. BUMDes as business entity that has characterized the village of Organizational Structure management, Venture Capital separately as well as the Statutes and Bylaws were obviously just established by Regulation village alone. As a Business Entity Rules necessarily besides Villages have legality strengthening elements (validity) who can strengthen establishment BUMDes.

In this study, the authors took the research sites in Semarang. By taking samples at seven (7) Village the Village of Lerep, Nyatnyono, Keji, Kalisidi, Mlilir, Gogik, and Kentheng. Semarang has 104 BUMDes spread in 19 sub-s and 121 villages. With the classification of the developing village-owned enterprises amounted to 6 BUMDes, BUMDes growth amounted to 45 BUMDes and basic BUMDes totaled 53 BUMDes $^{13}$. This number will change hand in hand with the development of BUMDes itself. According Prayitno functional as General in the Office of Rural Community Empowerment and Semarang, said ${ }^{14}$ : "When BUMDes that have been developed and leads to advanced, we turn to one form Rural Cooperation Agency. 2 Villages or more cooperation in the economic field point to BUMDes. But for the manager's name Cooperation Agency inter-village, now only leads there. The village still focus on the development in the scope of the village itself ".

Under the provisions of the above establishments of BUMDes together established pursuant to Rule Village or Village Head Joint Regulation. After a thorough writer in seven (7) Village No 3 Village the Lerep Village, Keji Village, and Nyatnyono Village who register BUMDes them to be listed in Authentic Notary Deed. While all four (4) other villages that Gogik Village, Kalisidi Village, Kenteng village, and Mlilir village use as a basis Regulatory Establishment BUMDes.

When viewed from the sense Deed Authentic, according to Abdul Ghofur Anshori, Authentic deed of Notary theoretically is a letter or a deed from the outset deliberately officially created for verification. Which means that since the beginning of the letter made it his goal to verification at a later date if there is a dispute ${ }^{15}$. While the notary

\footnotetext{
${ }^{12}$ Ibid., Article 7.

${ }^{13}$ Source: Department of Community Development of Semarang.

${ }^{14}$ Interview with Prayitno functional as General in the Department of Community Development of Semarang.

${ }^{15}$ Abdul Ghofur Anshori, 2009, Lembaga Kenotariatan Indonesia Perspektif Hukum dan Etika, UII Press, Yogyakarta, p. 18.
} 
itself is a public official authorized to make an authentic deed and have the other authorities referred to in this Act or under any other laws ${ }^{16}$.

"If the Notary deed made evident due to his fault or as knowing by evil intentions, then in this phase of Notary concerned can be used as a defendant ${ }^{17 "}$.

If $B U M D e s$ is a business entity which will undertake the legal relationship out, then in terms of increasing trust others to cooperate with BUMDes, is not enough just to village regulations, but also should get a strengthening of legality (validity) is required. Notary Deed is important because it has a clear Legal Certainty.

Legal certainty is a characteristic that can not be separated from the law, especially for a written legal norms. Law no certainty value will lose meaning because it no longer can be used as a code of conduct for everyone. Ubi jus incertum, ibi jus crimen (where there is no rule of law, there is no law). Legal certainty requires the creation of general rules or norm generally accepted, secure, and peaceful society. For the sake of it then the legal norms must be known with certainty. ${ }^{18}$

If the theory of legal certainty associated with the strengthening of legality Deed BUMDes establishment. BUMDes establishments must also entered in the Deed. Notary Deed will provide certainty and clarity in the legal actions BUMDes itself. What are the rights and obligations contained in the AD / ART BUMDes should be run according to what has been set.

In addition Deed as well as a form of legal protection because it can be used as evidence if a dispute later. The aim is to provide the aegis of legal protection of human rights are harmed by others and this protection is given to the public to be able to enjoy all the rights conferred by law ${ }^{19}$. Legal protection must see the stages of legal protection born of a legal provision and all the laws that society which is basically a community's agreement to regulate the relationship between the behavior of the members of society and between individuals and the government who are supposed to represent the public interest.

According Triyono, SH, M.Kn, as a Notary Public who make Deed for the third village stated that the Deed as well as a court decision which has permanent legal force. BUMDes notary deed of establishment makes reference is AD / ART BUMDes which is then validated by a notary ${ }^{20}$.

\subsection{Weaknesses and Solutions In The Preparation Of The BUMDES Deed}

Previous explanation the authors have explained about the formulation of the problem 1 in this research about how the force of law in Strengthening Legal Deed Establishment BUMDes based Perspective PERMENDESA No. 4 of 2015. Furthermore, the authors will present an explanation to answer the problem formulation.

Based on the reality on the ground for the establishment BUMDes Deed certainly experiencing weakness in terms of composition. As described by Triyono, SHMKn as

\footnotetext{
${ }^{16}$ Law of the Republic of Indonesia Number 2 of 2014 concerning the Amendment to Act No. 30 of 2004 About Notary Article 1.

${ }^{17}$ Nur Cahyanti, Sri Endah Wahyuningsih, "Sanksi Terhadap Notaris Yang Melakukan Tindak Pidana Menurut Peraturan Perundang-Undangan Di Indonesia", Jurnal Akta, Vol 5 No 1 Maret 2018: 288-294.

${ }^{18}$ Soerjono Soekanto, 1999, Beberapa Masalah Hukum dalam Kerangka Pembangunan di Indonesia (Suatu Tinjauan Secara Sosiologis), Universitas Indonesia, Jakarta, p. 55.

${ }^{19}$ M. Yahya Harahap, 2002, Pembahasan Permasalahan dan Penerapan KUHP Penyidikan dan Penuntutan, Sinar Grafika, Jakarta, p.76.

${ }^{20}$ Interview with Triyono, SH, M.Kn as a Notary Public in Batang.
} 
Notary Public ${ }^{21}$ explained that the weakness of the preparation of Deed as BUMDes establishment is as follows:

- When BUMDes want entered in the Deed, the Public Notary penghadap will meet with the AD / ART as reference material manufacture of Deeds. Each will have a format BUMDes AD / ART different raw formats owned by the Notary.

- Associated with the reference. Very minimal reference to the manufacture of Deed of Establishment relation to BUMDes. Because only affirmed that every village there must be $B U M D e s$ under Regulation village.

If $B U M D e s$ have a strong legal umbrella then the third party will be more trust to cooperate with BUMDes. Because before the units are already Enterprises in BUMDes limited liability or other legal entity Enterprises first step is to strengthen legality (validity) BUMDes itself. Because BUMDes is the parent of units contained therein Businesses need a clear guarantee Legal Certainty. Perception BUMDes hard and do not develop it's time we get rid of, basically if BUMDes is maximized then BUMDes is one of the community organizations that can improve the lives of the villagers. BUMDes not needed only complementary Village for their instructions from higher government but BUMDes is one institution that is needed by the people of the village to improve the welfare of the villagers, as contained in Article 3 PERMENDESA No. 4 of $2015^{22}$. That the establishment of BUMDes aims:

- Improve the economy of the village

- Optimizing asset to be beneficial to the welfare of the village of Desa.

- Improving the business community in the management of the economic potential of the Village

- Develop a plan of business cooperation between the villages and / or with third parties.

- CreaNPWPg opportunities and market networks that support public service needs of citizens.

- Create jobs

- Improve social welfare through the improvement of public services, economic growth and equitable distribution of the village; and

- Increase people's income and revenue village Desa.

Besides looking for a notary to be registered establishment Deed BUMDes into somewhat difficult. This is as what is conveyed by Bisri as Director BUMDes "Prosperity" as recorded BUMDes say ${ }^{23}$ : "Because not all Notaries understand, I know there is a Notary Deed also can create from a friend"

Of the weaknesses of the preparation of Deed of Establishment BUMDes certainly a Notary has the solutions to these problems. According Triyono, $\mathrm{SH}, \mathrm{M} . \mathrm{Kn}$ say ${ }^{24}$ : "The solution of the weaknesses associated with the preparation of the Deed of establishment BUMDes is experience, because every Notary not be able to make the format deed BUMDes"

The weakness of weakness in the preparation of the Deed of Establishment BUMDes be input need for regulation and a clear reference about the importance of the authentic act as the legality of the establishment of BUMDes. Notary as a public official authorized to make an authentic deed is also authorized to provide assistance and

\footnotetext{
21 Ibid.

22 Regulation of the Minister of Rural 42015 On the Establishment, Management and Administration, and the dissolution of the village-owned enterprises Article 3.

${ }^{23}$ Interview with Bisri as Director of village-owned enterprises "Prosperity."

24 Interview with Triyono, SH, M.Kn as a Notary Public in Batang.
} 
counseling to the community law in respect of the manufacture of Deeds as has been stated in Article 15 paragraph (2) letter (e) of Act No. 2 of 2014 concerning Notary. To the creation of Law Culture in society. ${ }^{25}$

However BUMDes are owned by citizens whose presence was necessary so that the village become more independent in managing potential village there, with the foundation of the crowing expected BUMDes not only as an activity which does not give any impact but can develop business units contained therein in order to contribute greatly to the progress of this nation.

\section{Closing}

\subsection{Conclusion}

Based on the research that has been done then the author can draw the conclusion that:

- Notary deed as a reinforcement of the legality of the establishment of BUMDes have binding legal force like the court decision and can provide legal certainty and legal protection in the future. BUMDes established by Regulation village formed by the village government and village Permusyawatan Board by consensus together. In addition to the legitimacy of the establishment of Village Regulations as BUMDes, reality on the ground there are some BUMDes in Semarang which have included Deed in strengthening the legality of the establishment. Notary makes Perdes and $A D$ / ART BUMDes as reference material manufacture of Deeds. Based on the research sample that uses Deed village in the Semarang is Lerep village, and the Keji village and Nyatnyono. Notary Deed also be the administrative requirements in the manufacture of NPWP when cooperation with third parties.

- Weaknesses in the establishment Deed preparation BUMDes based research are:

- As reference material manufacture BUMDes Deed establishment is AD / ART and Village Regulation. Each will have a format BUMDes AD / ART different and certainly not the same as the standard format of a Notary Public.

- References are minimal regarding creation BUMDes Deed of Establishment. Because in PERMENDESA No. 4 of 2015 only confirmed that each village can form BUMDes under Regulation village. Recording BUMDes establishment in the Deed is an initiative of the board BUMDes itself.

The solution of these weaknesses are: The solution of these flaws is the importance of knowledge and experience in making a Notary Deed BUMDes that in fact this is something new for most of the Notary.

Associated with the solution that has been mentioned in addition to the importance of the knowledge and experience of a Notary in making a deed, but also Notaries need to provide clarification of the law, the deed was made since the implementation of the duty office of Notary "Esteroic" which means needed special education and sufficient capacity to run, as in the case of duties required accuracy, precision and accuracy.

In addition, the Notary as public officials must be sensitive, responsive, has a sharpness of thinking and able to provide a proper analysis of any legal phenomenon and social phenomenon that appears so so will cultivate an attitude of courage in taking appropriate action.

\footnotetext{
${ }^{25}$ Law of the Republic of Indonesia Number 2 of 2014 on the Amendment of Act No. 30 of 2004 About Notary Article 15.
} 


\section{Bibliography}

[1] Ali, Z. 2009. Metode Penelitian Hukum. Jakarta: Sinar Grafika.

[2] Anshori, A. G. 2009. Lembaga Kenotariatan Indonesia Perspektif Hukum dan Etika. Yogyakarta: UII Press.

[3] Harahap, M. Y. 2002. Pembahasan Permasalahan dan Penerapan KUHP Penyidikan dan Penuntutan. Jakarta: Sinar Grafika.

[4] Soekanto, S. 1986. Pengantar Penelitian Hukum. Jakarta: UI Press.

[5] . 1999. Beberapa Masalah Hukum dalam Kerangka Pembangunan di Indonesia (Suatu Tinjauan Secara Sosiologis). Jakarta: Universitas Indonesia.

[6] Nur Cahyanti, S. E. (Vol 5 No 1 Maret 2018). "Sanksi Terhadap Notaris Yang Melakukan Tindak Pidana Menurut Peraturan Perundang-Undangan Di Indonesia". Jurnal Akta, 288-294.

[7] Law of the Republic of Indonesia Number 2 of 2014 on the Amendment of Act No. 30 of 2004 About Notary

[8] Act 6 of 2014 About the village.

[9] Regulation of the Minister of Rural 4 of 2015 On the Establishment, Management and Administration, and the dissolution of the village-owned enterprises. 